\title{
SCHELLINGOVY ÚVAHY O ZLU
}

\section{Martin Vrabec}

Schellingovy úvahy o zlu jsou v rámci filosofické tradice výjimečné a dodnes inspirativní. Schelling je na jednu stranu prvním myslitelem, který bere fenomén zla skutečně vážně a nesnaží se ho nijak odvysvětlit či bagatelizovat. Na rozdíl od předchozí tradice nepojímá zlo jako pouhou privaci dobra, ani se ho nepokouší zapojit do nějakého celkového vyššího smyslu, např. jakožto nutný prostředek k uskutečnění nejlepšího možného světa, nebo jako podnět k dějinnému a kulturnímu vývoji. ${ }^{1}$ Jeho snaha vypořádat se s nepopiratelnou a neredukovatelnou realitou zla ho pak nedovádí - na rozdíl např. od některých myslitelů vyrovnávajících se s hrůzami Osvětimi - $\mathrm{k}$ odmítnutí ontologie, v níž jsou př́roda i člověk s veškerými svými dějinami pochopeni jako boží stvoření a zjevení. Neupadá přitom ani do další možné krajnosti, kdy bývá zlo považováno za něco čistě faktického a nahodilého, co se naprosto vzpírá jakémukoli vysvětlení. Zlo má podle něj svůj původ, a ten leží mnohem hlouběji, než ho hledají všechna dnešní psychologicky či etologicky orientovaná vysvětlení. Chceme-li tento původ zla odhalit, musíme sestoupit na rovinu základních ontologických charakteristik všech konečných bytostí a na rovinu toho, co všechny tyto bytosti zakládá. Takovýto výzkum povahy a původu zla Schelling provádí především ve Filosofických zkoumánich bytnosti lidské svobody, ${ }^{2}$ která lidskou svobodu vymezují právě jako svobodu k dobru a ke zlu. Důležitá upřesnění k této otázce pak připojuje i ve Stuttgartských přednáškách, ${ }^{3}$ které pronesl jen rok po vydání svého spisu o svobodě.

1 F. Hermanni, Die letzte Entlastung. Vollendung und Scheitern des abendländischen Theodizeeprojekts in Schellings Philosophie, Wien 1994, str. 21.

2 F. W. J. Schelling, Über das Wesen der menschlichen Freiheit, vyd. T. Buchheim, Hamburg 2011 (=Freiheitsschrift; uvádíme standardní paginaci podle Schellingových Sämtliche Werke). Česky: F. W. J. Schelling, Filosofická zkoumání bytnosti lidské svobody a stím souvisejících předmětů, přel. M. Petř́iček, Praha 1992.

3 F. W. J. Schelling, Stuttgarter Privatvorlesungen, in: týž, Sämtliche Werke, I/7, vyd. K. F. A. Schelling, Stuttgart 1860, str. 421-484 (dále citováno jako Stuttgarter Privatvorlesungen). 
Vymezme si na začátek oblast, v níž můžeme podle Schellinga o zlu vůbec mluvit. Schelling vždy chápe zlo jako zlo způsobované člověkem a zla je podle něj schopen právě jen člověk. $V$ tomto smyslu nelze např. nemoc nebo prírodní katastrofy označit v pravém slova smyslu za zlé, jsou to jen jakési „předzvěsti“ či neúplné podoby zla. ${ }^{4} \mathrm{~V}$ silném slova smyslu může být zlé jen lidské jednání, resp. zlé mohou být jeho motivy a následky. Zla nejsou podle Schellinga schopna dokonce ani zvírata, a to kvůli své odlišné ontologické konstituci, kterou představíme níže. Právě z tohoto důvodu je podle Schellinga neudržitelná tradiční představa, podle níž je bezprostředním zdrojem zla naše smyslovost, tělesné žádosti, afekty atd., tedy to, co má člověk společné se zvířaty. Zlo může být naopak jen projevem toho nejdokonalejšího, co v člověku je a čím zvířata převyšuje, může být jen projevem lidské svobody a lidského ducha, byt' projevem zvrhlým. O tom nás ostatně podle Schellinga přesvědčuje i zkušenost: „Ten, kdo je alespoň trochu obeznámen s tajemstvím zla, ... ví, že nejvyšší zkaženost je též zkažeností nejduchovnější, že v ní vposled mizí všechno prírodní, a tudíž i smyslovost, a dokonce sama slast, ví, že tato zkaženost přechází v krutost a že démonicky a d'ábelsky zlý člověk má k požitku mnohem dál než člověk dobrý. ${ }^{\text {"5 }}$ Kým je tedy podle Schellinga člověk, jediná bytost schopná zla?

\section{I. Člověk jako podvojná bytost}

Člověk je jednak prŕrodní bytostí, která vstupuje do působných vztahů k ostatním prrírodním bytostem. Přitom stejně jako všechna ostatní konečná přírodní jsoucna musí mít v těchto vztazích nějakou svébytnost a stálost, musí být nějakým se sebou identickým subjektem, který do procesů sice vstupuje, ale nerozplývá se v nich. Takováto vnitřní identita každého konečného jsoucna se podle Schellinga projevuje za prvé jako jeho snaha setrvávat v existenci, a to nejen v existenci vůbec, ale i v určité podobě existence. Každé konečné jsoucno tak klade odpor vưči působení

4 V originálu „Vorzeichen“, tento výraz však nelze chápat časově, srv. F. W. J. Schelling, Freiheitsschrift, str. 376.

5 „Wer mit den Mysterien des Bösen nur einigermaßen bekannt ist ..., der wei $\beta$, da $\beta$ die höchste Corruption gerade auch die geistigste ist, da $\beta$ in ihr zuletzt alles Natürliche, und demnach sogar die Sinnlichkeit, ja die Wollust selbst verschwindet, da $\beta$ diese in Grausamkeit übergeht, und da $\beta$ der dämonisch-teuflische Böse dem Genu $\beta$ weit entfernter ist als der Gute.“ (F. W. J. Schelling, Stuttgarter Privatvorlesungen, str. 468). 
přicházejícímu zvnějšku, uzavírá se vnějšně způsobovaným změnám, a od vnějšku se tím odděluje. Druhý aspekt identity pak spočívá v tom, že každá konečná bytost je žádostivá, snaží se zachovat sebe sama prostřednictvím vnějšího působení a aktivního prosazování se, které se děje jako popírání či negování samostatnosti vnějších věcí, a tedy na úkor těchto vnějších věcí. ${ }^{6}$ Právě tyto dva dynamické aspekty utvářejí podle Schellinga svébytnost každého konečného jsoucna, utvářejí jeho samostatnost (Selbstständigkeit) a jeho svémoc (Selbstheit). ${ }^{7}$

Schelling ovšem nezůstává u pouhého konstatování a ve své theogonii, která je vždy zároveň kosmogonií, ukazuje, kde má tato svébytnost či svémoc jednotlivých stvoření svůj původ. Samostatnost či svémoc každého jednotlivého jsoucna podle něj koření v tzv. ,počátečním základu př́rody“ (anfänglicher Grund der Natur), ${ }^{8}$ který je totožný se základem (Grund) Boha samého, tedy s tím, co ještě není Bůh jakožto duch a jakožto láska. ${ }^{9}$ Tento společný základ př́rody i Boha je jakýmsi původním chaosem, který sice touží po existenci, postrádá však jakékoli pravidlo (Regelloses), jakoukoli formu a vnitřní jednotu, takže v něm nemůže existovat nic trvalého a stabilního. Schelling tento počáteční základ př́rody označuje jako „temný“ (dunkel), ${ }^{10}$ čímž ovšem nemíní primárně nějakou jeho „zlověstnou“ povahu, nýbrž právě absenci jakékoli vnitřní rozlišenosti a určitosti. Př́roda tak, jak ji známe, vzniká z tohoto temného základu tím, že se k němu připojí božské rozvažování, které je principem

6 Srv. souhrnnou formulaci: ,zajisté nelze mít za to, že žádost (Begierde), jež je základem každého zvláštního přírodního života, a pud setrvávat (Trieb sich... zu erhalten) nejen vůbec, nýbrž v tomto určitém existování, přistoupily ke stvořenému teprve dodatečně..."(F. W. J. Schelling, Freiheitsschrift, str. 376, česky str. 48). Takovouto dynamickou snahu o zachování vlastní identity vykazují nejen živé bytosti, ale lze ji v rudimentárnější podobě nalézt též u neživých těles. Srv. tamt., str. 370 (česky str. 43): ,inercii [hmoty] nelze myslet jako pouhou zbavenost, nýbrž je zajisté něčím pozitivním, totiž výrazem vnitřní svémoci (Selbstheit) tělesa, silou, kterou se těleso snaží prosadit svou samostatnost (Selbstständigkeit).“.

7 Termín „Selbstheit“ budeme právě kvůli silové, dynamické povaze tohoto „bytí sebou“" překládat jako „svémoc“.

8 F. W. J. Schelling, Freiheitsschrift, str. 378 (česky str. 48).

9 Srv. tamt., str. 359 (česky str. 33). Otázce, v jakém smyslu je „základ Boha“ také ,základem př́írody“, se zde pro její obšírnost nemůžeme věnovat. K tomuto tématu viz např. přehlednou studii F. Hermanni, Der Grund der Persönlichkeit Gottes, in: T. Buchheim - F. Hermanni (vyd.), ,, Alle Persönlichkeit ruht auf einem dunkeln Grunde. “ Schellings Philosophie der Personalität, Berlin 2004, str. 165-178, zvl. str. $169 \mathrm{n}$.

10 Srv. např. F. W. J. Schelling, Freiheitsschrift, str. 362 (česky str. 36). 
artikulované, rozlišené jednoty, a z tohoto důvodu ho Schelling označuje též jako světlo či Slovo (ve smyslu biblického logos). ${ }^{11}$ Toto božské rozvažování podněcuje neuspořádané síly k vzájemnému rozlišení, k ustavení stabilních pojmových a působných vztahů mezi nimi, a z původního chaosu se tak ustavuje př́roda jakožto vnitřně artikulovaná jednota rozmanitých jednotlivých jsoucen. Stvoření je tedy podle Schellinga zjevováním božského rozvažování ve sfeerée reálného neboli v tom, co pochází z onoho temného základu přírody. Stvoření je zároveň též zjevováním boží lásky, nebot' Bůh jakožto láska je tím, kdo takříkajíc drží oba principy pohromadě, byt' by mohly existovat nezávisle na sobě a jeden bez druhého. ${ }^{12}$ Temný základ př́rody se přitom aktivně brání působení boží lásky a božího rozvažování, uzavírá se veškeré artikulaci a veškerému rozlišování, ${ }^{13}$ což vede $\mathrm{k}$ tomu, že $\mathrm{k}$ ovládnutí a prosvětlení chaosu nedochází ,jedním rázem“, nýbrž jde o postupný proces, v němž díky souhře progresivně působícího rozvažování a regresivně působícího „základu“ vznikají rozmanité vývojové stupně př́rody. ${ }^{14} \mathrm{~V}$ našem kontextu je ovšem důležitější, že i každé jednotlivé jsoucno, nakolik pochází z tohoto temného základu, vykazuje odpor vůči rozlišenosti, vůči vnitřní i vnější diferenciaci, a právě tento odpor a snaha uzavírat se do sebe utváŕí jeho svémoc a samostatnost vůči všem ostatním jednotlivým jsoucnům.

11 Srv. tamt., str. 361, 363 (česky str. 35, 37). Srv. též F. W. J. Schelling, Stuttgarter Privatvorlesungen, str. $442 \mathrm{n}$.

12 Srv. F. W. J. Schelling, Freiheitsschrift, str. 408 (česky str. 75): „Tajemství lásky... je v tom, že spojuje, co samo by mohlo být i pro sebe, a přece pro sebe není a bez druhého nemůže být.“ (Podobně též Stuttgarter Privatvorlesungen, str. 453.)

13 Srv. F. W. J. Schelling, Freiheitsschrift, str. 361 (česky str. 35) (překlad upraven): „Rozvažováním podrážděná (erregt) touha se ted' snaží... uzavřít v sobě samé, aby napořád zůstávala základem.“ Tamt., str. 404 (česky str. 71): „Světlo neboli ideální princip je jakožto věčný protiklad temného principu tvořivým slovem, které vykupuje z nebytí život pohroužený do základu a z potence jej vyzdvihuje k aktu. Nad slovem se klene duch a duch je též první bytost, která spojuje svět temnoty se světem světla... Avšak proti této jednotě se bouří základ a prosazuje původní dualitu..."

14 Srv. F. W. J. Schelling, Stuttgarter Privatvorlesungen, str. 434: „Ona nevědomá stránka Boha je ovšem stejně nekonečná jako on sám, takže není tak rychle vyčerpána, a proto také trvá proces stvoření světa tak dlouho (daher die Dauer des Processes der Weltschöpfung).“ Necháváme zde otevřenou otázku, v jakém ohledu Schelling pojímá vznik prŕrody (tj. prŕrody v běžném slova smyslu) jako proces probíhající v čase, nebot' tato otázka není zásadně dủležitá pro naše celkové téma. 
Po krátkém exkursu o povaze všeho stvoření se vrat'me k člověku. Ten je sice př́rodní bytostí vzešlou z temného základu, od všech ostatních stvořených bytostí se však zásadně odlišuje tím, že není jen produktem postupného zjevování se rozvažování $\mathrm{v}$ prrírodě, nýbrž toto rozvažování také sám má a je „nositelem a jaksi schránou vyššího principu světla“. ${ }^{15}$ To je zajisté třeba blíže vysvětlit. V člověku se podle Schellinga rozvažování osvobozuje od své bezprostřední vázanosti na reálné, už se v tomto reálném nejen objektivně uskutečňuje, ale poprvé v procesu vývoje př́rody vystupuje také jako ono samo, jako subjekt, pro nějž se stává předchozí rovina organična pouhým předmětem a nástrojem. Toto lidské rozvažování přitom není totožné s božím rozvažováním, je pouhým obrazem božího rozvažování vzešlým ve sféře stvořeného, což Schelling formuluje tak, že člověk byl sice stvořen $v$ centru ${ }^{16}$ a jistým způsobem se podílí na centru všeho stvoření - totiž právě na božím rozvažování a boží moudrosti -, ${ }^{17}$ ale tímto centrem sám není. Takovéto „mezipostavení“ lidského rozvažování s sebou nese, že boží rozvažování vystupuje pro člověka jako transcendentní míra, s níž může být jeho vlastní rozvažování v souladu, ale také nemusí. Právě z tohoto důvodu Schelling v některých pasážích rozlišuje mezi lidským rozvažováním (Verstand) a lidským rozumem (Vernunft), přičemž rozum je pro něj oním místem, na němž člověk přijímá boží moudrost, kdežto rozvažování je aktivní schopností, která by se měla řídit rozumem, resp. boží moudrostí, ale může jich také nedbat a vzepř́ít se jim. ${ }^{18}$

\section{Dvě podoby syntézy: dobro a zlo}

Doposud jsme viděli, že člověk je podle Schellinga na jednu stranu př́rodní bytostí, na druhou stranu disponuje rozvažováním, díky němuž rovinu prosté přírody překračuje. I přes tuto svoji podvojnost však musí být vnitřně jednotnou bytostí, a tento jednotící moment člověka

15 F. W. J. Schelling, Freiheitsschrift, str. 364 (česky str. 38).

16 Tamt., str. 411 (česky str. 77): „Pouze člověk je v Bohu... Jedině člověk je bytostí centrální (Centralwesen), a proto je jeho místo v centru.“ Tamt., str. 381 (česky str. 53): „Sama životní úzkost vyhání člověka z centra, do nějž byl stvořen..."

17 Viz Schellingovo tvrzení, že vůle ostatních bytostí ,ještě není povznesena k úplné jednotě se světlem (jako principem rozvažování), ještě ho neuchopila [nicht fasst].“ (F. W. J. Schelling, Freiheitsschrift, str. 363, česky str. 36, překlad upraven).

18 Srv. F. W. J. Schelling, Freiheitsschrift, str. 414 n. (česky str. 80); týž, Stuttgarter Privatvorlesungen, str. $471 \mathrm{n}$. 
Schelling označuje jako ducha. Právě duch je podle něj onou schopností, která vytváŕí svobodnou syntézu mezi oběma konstitutivními momenty člověka, ${ }^{19}$ totiž mezi jeho př́rodností, díky níž je partikulární a svémocnou bytostí, a vědomím celkového božího řádu. Jaká je povaha této syntézy?

Podívejme se nejprve, v jakém smyslu je tato syntéza svobodná. Člověk jakožto duch je jednak svobodný vůči přírodě, je - jak říká Schelling - „nad prŕrodou“ ${ }^{20}$ a to jak nad přírodou vnitřní, tak nad přírodou vnější. Vůči vnitřní prírodě je svobodný v tom smyslu, že duch - na rozdíl od duše ${ }^{21}$ - dokáže sjednocovat lidské žádosti, pudy a instinkty na základě rozvažování, tj. uspořádává je vzhledem ke svým obecným představám o cílech jednání a dokáže tyto žádosti či pudy využít jako nástroje k dosažení takovýchto cílů, ${ }^{22}$ což ovšem ještě neznamená, že by tyto cíle musely být nutně v souladu s celkovým božím řádem. Zvířecí duše naproti tomu dává mnohosti žádostí a instinktů jen nevědomou jednotu, v níž zůstávají jednotlivé žádosti a instinkty specializované, jsou vázány $\mathrm{k}$ úzce vymezeným cílům a umožňují jen velmi úzkou paletu jednání. ${ }^{23}$ Právě kvůli tomuto rozvažovacímu odstupu od jednotlivých žádostí a instinktů, který ruší jejich původní vázanost na konkrétní a úzce vymezené okolnosti, lze člověka označit jako universální bytost. Universální bytostí je člověk rovněž v tom smyslu, že pro něj díky rozvažování

19 Schelling hovoří o tom, že duch vytváří ,živou identitu“ (lebendige Identität) či ,sponu“ (Band) mezi oběma konstitutivními principy člověka (F. W. J. Schelling, Freiheitsschrift, str. 362 nn. (česky str. 36 n.).

20 F. W. J. Schelling, Freiheitsschrift, str. 364 (česky str. 38); týž, Stuttgarter Privatvorlesungen, str. 458.

21 O rozdílu mezi „duši “ a „duchem“ zde mluvíme tak, jak je zaveden ve Freiheitsschriftu, kde „duše“ vystupuje jako „živá spona“ a „centrum“ rozmanitých sil, z nichž je konfigurováno tělo jednotlivé živé bytosti - srv. F. W. J. Schelling, Freiheitsschrift, str. 362 (česky str. 36). Oproti tomu ve Stuttgarter Privatvorlesungen onomu přírodnímu aspektu člověka, který sdílí se všemi ostatními živými bytostmi, odpovídá „mysl“ (Gemüth) a Schelling zde výraz „duše“ (Seele) rezervuje pro to, co je v člověku božské a neosobní - srv. F. W. J. Schelling, Stuttgarter Privatvorlesungen, str. 465-469.

22 Srv. F. W. J. Schelling, Freiheitsschrift, str. 376, pozn. (česky str. 48): „Už dokonalé rozvinutí pomocných orgánů, které dostoupilo svého vrcholu u člověka, totiž poukazuje na nezávislost vůle na žádostech čili na vztah centra a periférie, který je zdravý pouze tehdy, jestliže centrum ustoupilo ve své svobodě a osvícenosti a odlišilo se od pouze nástrojového (periferního).“

23 F. W. J. Schelling, Stuttgarter Privatvorlesungen, str. 456. 
vystupuje universum, přiroda jako celek, a tato příroda se pro něj stává předmětem, který může svobodně přetvářet a využívat. ${ }^{24}$

Člověk jakožto duch ale disponuje svobodou nejen vůči přírodě, nýbrž je svobodný - jak již jsme naznačili - i vưči božímu rozvažování a z něj pocházejícímu řádu universa. Tuto svobodu vůči Bohu má člověk díky tomu, že je bytostí vzešlou z temného základu přírody, z toho, co v Bohu není Bůh sám, a je tedy svémocnou, vůči Bohu relativně samostatnou bytostí.

Samotná svobodná syntéza, již duch vytváří mezi naší partikularitou a svémocí na jedné straně, a naším vědomím universálního řádu na straně druhé, nemůže být nějakým neutrálním sloučením obou konstitutivních momentů, nebot' tyto momenty orientují lidské jednání zcela opačnými směry, a pokud by oba zůstaly stejně platné, $\mathrm{k}$ žádnému jednání by nikdy nedošlo. Svobodná syntéza může proto mít jen podobu podřizení jednoho momentu druhému a je vždy rozhodnutím, vposled rozhodnutím o dobré či zlé povaze našeho jednání. Člověk tak bud' může svoji vůli jakožto vůli partikulární bytosti podřídit vůli universální, onomu božímu řádu universa, který vede $\mathrm{k}$, jednotě a mírnosti“" ${ }^{\text {25 }}$ všech věcí, a takovýto člověk pak jedná dobře. Neznamená to však, že by se v dobrém jednání jeho svémoc a samostatnost úplně ztrácela, tato svémoc se spíše nechává proniknout (durchdringen) onou universální boží vưlí a bere ji jako měřítko svého jednání. V takovémto člověku pak přestává být svémoc jeho posledním cílem a stává se nástrojem universální vůle, díky čemuž pak nachází smírné vztahy se vším ostatním stvořeným - tedy alespoň do té míry, do níž je to v daném dějinném okamžiku možné.

Poznamenejme v této souvislosti, že u všech nižších tvorů je takovéto podřízení se universální vůli automatické, vlastní vůle takovýchto bytostí je takř́ikajíc za jejich zády koordinována jim vnější universální vůlí - prríkladem by mohl být rozmnožovací pud, kdy daný jedinec hledá jen své vlastní uspokojení, ale přispívá tím k zachování a udržení celého druhu. Nižší tvorové se universální vůli nepodřizují svobodně, a nemohou být proto v silném slova smyslu dobří, nemohou však být ani zlí, nebot' nemohou převrátit onu náležitou jednotu obou principů. ${ }^{26}$ Podle

24 Tento negativní vztah ducha k přírodě Schelling v Stuttgarter Privatvorlesungen spojuje s ohnivou povahou ducha, duch je podle něj neuhasitelným, stravujícím a ze sebe žhnoucím plamenem, srv. F. W. J. Schelling, Stuttgarter Privatvorlesungen, str. 466. Jde o Schellingovo rozvinutí biblického příměru Ducha svatého $\mathrm{k}$ plameni.

25 F. W. J. Schelling, Freiheitsschrift, str. 409 (česky str. 76, překlad upraven).

26 Srv. tamt., str. 372 (česky str. 44 n.). 
Schellinga „by si [proto] bylo přát, aby zkaženost v člověku nešla dále než k jeho zezviŕrečtění; bohužel však člověk může stát bud' nad zvířetem, anebo pod ním“. ${ }^{27}$

Druhá možná podoba svobodné syntézy, která je vlastní pouze člověku, pak spočívá v tom, že se vzepře oné universální vưli, neřídí se jí a upřednostní svoji vlastní vưli jakožto vưli jednotlivé bytosti. Právě toto povýšení vlastní vůle nad vůli universální je podle Schellinga pramenem a společným znakem všech rozmanitých podob zlého jednání. Takovéto povyšování vlastní vůle ovšem opět nevede $\mathrm{k}$ tomu, že by druhý princip úplně zmizel, i zlý člověk zůstává člověkem a vykazuje jistý aspekt universality - i nadále myslí a zohledňuje obecné vztahy a souvislosti -, jeho rozvažování se však osamostatňuje, odvrací se od své míry, totiž božského rozvažování či řádu, a jeho řídícím principem se stává svémoc (Selbstheit). ${ }^{28} \mathrm{Na}$ tomto zachování obou konstitutivních principů i ve zlu můžeme dobře vidět, $v$ jakém smyslu se Schelling rozchází s předchozí tradicí, podle níž je zlo něčím čistě negativním, nějakým chyběním dokonalosti či pozitivního principu. Zlo je v jeho pojetí syntézou dvou pozitivních principů, a tak samo něčím pozitivním a reálným, obdobně jako dobro, je však zároveň syntézou převrácenou či zvrácenou, ${ }^{29} \mathrm{kdy}$ se vlády ujímá princip, který měl zůstat podřizený. To pak s sebou nese jeho dvojaký status, kdy je jednak něčím reálným a působným, ale ve srovnání s náležitou a pravou jednotou obou principů zároveň vystupuje jako něco relativně nejsoucího. ${ }^{30}$

27 Tamt., str. 373 (česky str. 45). Srv. rovněž tamt., str. 368 (česky str. 41).

28 Srv. tamt., str. 365 (česky str. 39, překlad upraven): „Vůle... opouští své místo nad stvořeným, aby se jako obecná vůle učinila zároveň i vůlí dílčí neboli vůlí tvora..."V Stuttgarter Privatvorlesungen označuje Schelling krajní podobu tohoto stavu jako šílenství (Wahnsinn), které není opakem rozvažování, nýbrž je samotným jeho základem, jenž je regulován a přemáhán jen díky vztahu k božské míře (srv. F. W. J. Schelling, Stuttgarter Privatvorlesungen, str. 469 n.).

29 Srv. F. W. J. Schelling, Freiheitsschrift, str. 366 (česky str. 40): „Tento jedině správný pojem zla, podle kterého zlo záleží v pozitivním zvrácení či převrácení principů..."

30 Srv. F. W. J. Schelling, Stuttgarter Privatvorlesungen, str. 459: „Nebot’ zlo není právě ničím jiným než něčím relativně nejsoucím (relativ Nichtseyende)... Na jednu stranu je ničím (Nichts), na druhou stranu je nanejvýš reálnou bytností (höchst reelles Wesen).“ Tamt., str. 436 n.: „Zlo je v morálním světě tím, čím je nemoc ve světě tělesném; na jednu stranu je tím krajně nebytostným (entschiedenstes Nichtwesen), a přece má strašlivou realitu (schreckliche Realität).“ Týž, Freiheitsschrift, str. 366 (česky str. 40): „A jako ovšem není choroba ničím bytostným a [je] vlastně jen zdáním života a pouze meteorickým jevem - kolísáním mezi bytím a ne- 
Co je pak cílem, k němuž směřje jednání zlého člověka? Připomeneme-li si výše uvedené úvahy o svémoci, z nichž vyplývá, že identita se sebou každé konečné věci má silovou povahu, nepřekvapí nás, že zlému člověku podle Schellinga nejde jen o prosté zachování sebe sama jakožto jednotlivého individua a nejde mu vposled ani o získání nějaké smyslové libosti či slasti. ${ }^{31}$ Principem tohoto jednání tedy není jen sebeláska, nýbrž zlému člověku jde podle Schellinga vposled o prosazení jeho vlastní moci, takovýto člověk chce vše ostatní ovládnout a podřídit to své vlastní partikulární vůli. Jak na jednom místě explicitně říká Schelling, zlý člověk chce sebe sama učinit tvořicím základem a chce vládnout nad všemi věcmi.$^{32}$ Př́ípady takto motivovaného jednání bychom zajisté našli nejen na rovině individuální, ale i na rovině společenské. Schellingovy úvahy jsou např́klad v mnohém blízké analýzám totalitarismu, jak je známe od Hannah Arendtové, ale dokáží výstižně popsat i napjatý lidský vztah $\mathrm{k}$ prrírodě, kdy lidstvo k prosazení své přirozené snahy o sebezachování užívá rozvažování, což mu nad přírodou dává nevídanou moc, která posléze přesahuje všechny jeho reálné potřeby a stává se sama pro sebe cílem. ${ }^{33}$

\section{Radikální zlo}

Schelling ovšem ve svých analýzách popisuje ještě krajnější podobu zla. Snaha jednotlivé bytosti afirmovat svoji moc může podle něj zajít až tak daleko, že vede k pustému ničení všeho ostatního, kdy cílem už je jen ničení samo. Ve Stuttgartských prednáškách se tak můžeme dočíst, že „zlo vede... nejurputnější válku proti všemu bytí, chce dokonce zničit

bytím -, třebaže se našemu pocitu hlásí jako cosi nadmíru reelního, právě tak se to má i se zlem."

31 Viz úvodní citát (pozn. 5), podle nějž při konání extrémního zla mizí veškerá slast a veškerý požitek.

32 F. W. J. Schelling, Freiheitsschrift, str. 390 (česky str. 60): „Počátek hříchu je tedy ten, že člověk opustí pravé bytí..., aby se sám učinil tvořícím základem a nad všemi věcmi vládl mocí centra, které nosí v sobě. Nebot' i ten, kdo se z centra odchýlil, stále ještě cítí, že byl kdysi vším, totiž v Bohu a s Bohem, a proto tíhne opět zpět - avšak pouze pro sebe a nikoli tam, kde by zase mohl být vším, k Bohu.“

33 Srv. V. Hösle, Praktische Philosophie in der modernen Welt, München 1992, str. 166-197 (citováno podle S. Žižek, The Invisible Remainder, London - New York 2007, str. 63). 
základ všeho stvoření“. ${ }^{34}$ Takovéto radikální zlo, jehož cílem je ničení pro ničení, patrně musí mít hlubší motiv než jen výše uvedenou snahu prosadit svoji moc a afirmovat sebe sama jakožto partikulární, individuální jsoucno. V čem by tento motiv mohl spočívat? Klíč nám k tomu poskytuje jedna zajímavá a v sekundární literatuře opomíjená pasáž, v níž Schelling tvrdí: „Všechna existence vyžaduje podmínění... Člověk [však na rozdíl od Boha $-\mathrm{M}$. V.] tuto podmínku svou mocí nikdy neovládne, třebaže se o to ve zlu snaží, nebot' je mu pouze propůjčena, je na něm nezávislá: proto nemůže svou osobnost ani svémoc nikdy povznést k dovršenému aktu. Tot' ona chmura, která halí všechen konečný život. ... Proto onen háv těžkomyslnosti, jímž je obestřena př́roda jako celek, hluboká a nevykořenitelná melancholie všeho života. ${ }^{\text {"35 }}$ Podle této pasáže by zlo mělo být výsledkem snahy přemoci určitou na nás nezávislou podmínku (Bedingung), a tím dovršit svoji svémoc (Selbstheit). Touto podmínkou je zde míněn onen „základ přírody“ čili všeobecné „médium“ , ${ }^{36} \mathrm{z}$ něhož každá jednotlivá bytost pochází a z něhož se jakožto partikulární a určitá vyděluje. Pro každé jednotlivé jsoucno odlišné od jiných jednotlivých jsoucen je ovšem nevyhnutelné, že jakožto jednotlivé musí též zaniknout a opět se v onom médiu rozplynout. Proto se podle Schellinga vše živé vposled touží zbavit své partikularity a s ní spojené konečnosti, touží nebýt již jen partikulárním jsoucnem mezi ostatními partikulárními jsoucny, chce si naopak přisvojit ono všeobecné médium, chce se jím samo stát, a tím se vyhnout zániku. Takováto touha je podle Schellinga touhou melancholickou, protože je „truchlením po ztraceném dobru“, ${ }^{37}$ po prvotní nerozlišenosti v rámci temného základu př́rody. Ono zbavení se partikularity a kýžená sebeidentifikace s temným základem přitom nemá být žádnou rezignací na svojskost (Selbstheit), má být naopak způsobem, jak si ji uchovat a dovršit. Radikální zlo tedy podle Schellinga pramení z podlehnutí melancholické touze, kdy se člověk snaží svoji partikularitu

34 F. W. J. Schelling, Stuttgarter Privatvorlesungen, str. 468: „,Das Böse... führt den heftigsten Krieg gegen alles Seyn, ja es möchte den Grund der Schöpfung aufheben." Srv. též F. W. J. Schelling, Freiheitsschrift, str. 365 (česky str. 39, zvýraznil M. V., překlad upraven): „Vůle, která opouští své místo nad stvořeným, aby se jako obecná vůle učinila zároveň i vůlí dílčí neboli vůlí tvora, se snaží... užívat ducha... proti tvoru (gegen die Kreatur), z čehož pochází rozklad v ní i mimo ni.“

35 F. W. J. Schelling, Freiheitsschrift, str. 399 (česky str. 66 n., zvýraznil M. V.).

36 Termín „médium“ přebírám v této souvislosti od Thomase Buchheima (T. Buchheim, Anmerkungen des Herausgebers, in: F. W. J. Schelling, Über das Wesen der menschlichen Freiheit, Hamburg 2011, str. 113, pozn. 102).

37 Viz F. W. J. Schelling, Stuttgarter Privatvorlesungen, str. 465 n. 
a s ní nevyhnutelně spojenou pomíjivost překonat tím, že neguje a ničí vše ostatní jednotlivé, a chce se tak stát vším v tom smyslu, že bude tím jediným jsoucím, tím jediným, co nakonec zůstane. Je ovšem zřejmé, že takovýto způsob oproštění se od vlastní partikularity je předem odsouzen k nezdaru. Poznamenejme, že i konání dobra by v této souvislosti bylo možné považovat za způsob, jak uniknout nesnesitelné partikularitě a pomíjivosti lidského života. Vždyt' i dobrý člověk se snaží odumřít své partikularitě, a to tím, že svoji vlastní vůli podřizuje vůli boží, a chce se tak stát nástrojem božího řádu přesahujícího vše jednotlivé a konečné.

\section{Hněv boží}

Viděli jsme, že člověk, který propadl zlu, v poslední instanci nechce ničit jen jednotlivé věci či bytosti kolem sebe, ale vztahuje ruku na samotný celek stvoření. Právě toto nejzazší směřování všeho zla podle Schellinga vysvětluje, proč na zlé jednání nepohlížíme jen jako na sice politováníhodný, ale vposled omluvitelný výsledek lidského pudu sebezáchovy, jako na výsledek pouhé neschopnosti nalézt nějaký méně destruktivní modus vivendi. Zlo v nás vyvolává mnohem silnější pocity, totiž zděšení a hrůzu, ${ }^{38}$ které pramení z toho, že ve zlu se aktivuje původní děsivá povaha Boha a zlo rozpoutává boži hněv. Tento boží hněv si ale nemůžeme představovat jako nějaký zvnějšku přicházející trest za naše zlé činy. Abychom správně pochopili, jakým způsobem zde Schelling reinterpretuje tradiční motiv božího hněvu, musíme si připomenout ontologickou strukturu stvořeného světa: Výše jsme uvedli, že stvořený svět, resp. príiroda tak, jak ji známe, má svůj základ v prvotní bytnosti Boha, v tom, co ještě neni Bůh jakožto duch a jakožto láska. Tento společný základ Boha i přírody má povahu temného, do sebe se uzavírajícího chaosu sil, a právě proto, že v něm ještě nemůže existovat nic stabilního a rozlišeného, tj. žádná jednotlivá jsoucna, označuje ho Schelling také jako egoismus boží, jako původní děsivou bytnost Boha, která je nepřátelská všemu jednotlivému jsoucímu. ${ }^{39}$ Viděli jsme také, že Bůh překonává svůj egoismus tím,

38 Srv. F. W. J. Schelling, Freiheitsschrift, str. 391 (česky str. 60, překlad upraven): „Nebot’ na zjevný hřích nehledíme s politováním jako na nějakou slabost anebo neschopnost, ale s hrůzou (Schrecken) a zděšením (Horror), což je pocit vyložitelný jen tím, že hř́ch usiluje porušit Slovo, vztáhnout ruku na sám základ stvoření a zprofanovat mystérium."

39 Srv. F. W. J. Schelling, Stuttgarter Privatvorlesungen, str. 439: „Boží egoismus je základní bytností (Grundwesen) přírody."F. W. J. Schelling, Freiheitsschrift, 
že v této své původní děsivé bytnosti nechává vzniknout stabilním rozlišením, artikuluje tuto svoji děsivou bytnost, a v tomto smyslu ji spoutává a tlumí, dělá z ní právě jen základ stvořeného světa, který se nijak aktivně neprojevuje. ${ }^{40}$ Když tedy zlý člověk ve svém jednání vztahuje ruku na samotný řád dávající veškerému stvoření stabilitu a rozlišitelnost, ničí svým jednáním pouta svazující onu hrozivou původní bytnost př́rody, resp. Boha. Tato děsivá bytnost se díky tomu uvolňuje, stává se z něčeho ovládnutého a zatlačeného do pouhé potenciality něčím aktuálním, propuká jakožto onen původní chaos, který stravuje a spaluje vše stabilní a vymezené. ${ }^{41}$ Zlé jednání v nás tedy nezpůsobuje zděšení a hrůzu proto, že neničí jen jednotlivé bytosti - to koneckoncủ dělá i smrt -, ale proto, že ničí pouta všeho stvoření, a tím ve svém nejzazším směřování ohrožuje svět jako celek.

\section{Závěr}

Otázku po povaze a původu zla si Schelling kladl v rámci širšího problému, totiž jak smířit existenci lidské svobody s tím, že celek všeho jsoucího má povahu systému, v němž vládne nutnost. Ve svých úvahách dochází k závěru, že má-li být možná lidská svoboda, musí v Bohu samém, a potažmo i ve všech stvořených bytostech, existovat dva konstitutivní a stejně věčné principy, totiž na jedné straně princip svémoci čili individuality, a na druhé straně princip božského rozvažování čili universality. Jedině díky podílu na božském rozvažování a universalitě je totiž člověk svobodný vůči př́rodě, díky vlastní svémoci je pak svobodný vůči Bohu. Právě tato specifická ontologická koncepce, která má zachránit lidskou svobodu, pak Schellingovi poskytuje i nástroj, jímž se snaží překonat nedostatky tradičních představ o povaze a původu zla. Zlo totiž nelze podle jeho názoru považovat za pouhé chybění dobra, za pouhou

str. 391 (česky str. 60, překlad upraven): „,. bytnost Boží, která je jaksi před vší existencí (je tedy ještě neztlumená existencí), a proto je strašlivá (schrecklich).“

40 Srv. F. W. J. Schelling, Stuttgarter Privatvorlesungen, str. 439: „... skutečná živoucí příroda, tak jak ji před sebou vidíme, je božím egoismem, který již byl přemožen a zmírněn boží láskou." Srv. též Freiheitsschrift, str. 391, 405, 408 (česky str. 60, 71 n., 75 n.).

41 Srv. F. W. J. Schelling, Freiheitsschrift, str. 391 (česky str. 60); F. W. J. Schelling, Stuttgarter Privatvorlesungen, str. 438: „stravující oheň (verzehrendes Feuer)“; tamt., str. 439: „hněv Boží (Zorn Gottes)“; tamt., str. 448: „oheň hněvu (Zornfeuer)“. 
pasivitu a nepř́istupnost vưči dobrým jednáním, nebot' by to znamenalo bagatelizovat jeho nepopiratelnou realitu i jeho děsivé následky. Zlo je podle něj naopak projevem aktivního a svobodného převrácení náležité jednoty těchto dvou principů, kdy je lidské jednání vedeno principem svémoci, místo aby bralo ohled na universální řád veškerého stvoření. Je-li tomu ale tak, že zlé jednání je vedeno snahou prosadit svoji vlastní vůli a svoji vlastní moc, pak bychom podle Schellinga měli revidovat i tradiční představu, že posledním cílem zlého jednání je získat nějaká smyslová potěšení či hmotné výhody. Pokud tak skutečně učiníme, stane se pro nás pochopitelnou i existence radikálně zlého jednání, které žádné smyslové požitky a výhody nepřináší a jehož cílem už je jen ničení pro ničení. Chceme-li ale motivy radikálně zlého jednání pochopit úplně, nestačí poukázat jen na to, že zlé jednání je vedeno snahou prosadit svoji moc. V pozadí této snahy, a tedy i v pozadí všech zlých jednání, stojí podle Schellinga touha uniknout vlastní partikularitě a pomíjivosti, jež jsou údělem každého konečného jsoucna. Konání zla je jen jednou z možných cest, po níž může člověka tato touha vést, a pokud se po ní vydá, pak jeho jednání oprávněně vzbuzuje zděšení. Svými činy totiž podle Schellingovy ontologické koncepce neškodí jen jiným lidem a neničí jen jednotlivé věci či vztahy, ale uvolňuje a rozpoutává síly původního chaosu, který je děsivým základem a podložím vší reality.

\section{ZUSAMMENFASSUNG}

Die Studie konzentriert sich auf Schellings Gedanken über das Wesen des Bösen und zeigt, auf welcher Weise Schelling den traditionellen Begriff des Bösen als lediglich passiven Mangel an Gutem und als etwas, das aus unseren Sinnen stammt, d.h. aus dem, was wir mit Tieren gemeinsam haben, revidiert. Denn nur der Mensch ist nach Schelling in der Lage, Böses zu tun, und alle seine bösen Taten entstehen infolge der aktiven Durchsetzung seines individuellen Willens und seiner Macht auf Kosten des Ganzen. Auf der Grundlage einer detaillierteren Analyse des Themas des radikalen Bösen zeigt die Studie, dass das tiefste Motiv des bösen Handelns das menschliche Verlangen ist, seiner eigenen Partikularität und Vergänglichkeit zu entfliehen. Der letzte Teil der Studie befasst sich mit dem kosmologischen Aspekt von Schellings Konzeption des Bösen und mit seiner Neuinterpretation des traditionellen Motivs von Zorn Gottes. 


\section{SUMMARY}

The study focuses on Schelling's thoughts about the nature of evil, and shows how Schelling reworked the traditional concept of evil as merely a passive lack of good and as something that comes from our senses, i.e. from what we have in common with animals. For only man is, according to Schelling, capable of evil and all his evil actions arise by actively promoting his individual will and power at the expense of the whole. Based on a more detailed analysis of the theme of radical evil, the study shows that the deepest motive of evil conduct is, according to Schelling, the human desire to escape one's own particularity and transience. The last part of the study deals with the cosmological aspect of Schelling's concept of evil and with his reinterpretation of the traditional motif of the wrath of God. 